\title{
MAPPING SPATIO-TEMPORAL CHANGES IN CLIMATIC SUITABILITY OF CORN IN THE PHILIPPINES UNDER FUTURE CLIMATE CONDITION
}

\author{
ARnold R. SAlvacion \\ Department of Community and Environmental Resource Planning, College of Human Ecology, University \\ of the Philippines Los Baños, Laguna, Philippines
}

Manuscript received: November 3, 2016

Revised version: February 9, 2017

\begin{abstract}
SALVACION A.R., 2017. Mapping spatio-temporal changes in climatic suitability of corn in the Philippines under future climate condition. Quaestiones Geographiceae 36(1), Bogucki Wydownictwo Naukowe, Poznań, pp. 105-120, 11 figs, 5 tables.

ABSTRACT: This study assessed the spatio-temporal changes in corn climatic suitability in the Philippines under future climate condition. Using extracted climatic data from WorldClim database for the country under baseline and future climate condition, changes in corn suitability was assessed using fuzzy logic approach and published rainfall and temperature requirement of the crop. Based on the data, the large portion of the country will experience increase in monthly total rainfall $(88 \%)$ while increase in monthly mean and minimum temperature under future climate condition is projected for the entire country. These increases in rainfall and temperature resulted in changes of corn climatic suitability in the country depending on the month and location. On the average, changes in rainfall resulted in reduction $(8 \%)$ and improvement $(6 \%)$ in corn suitability while increase in temperature resulted in $5 \%$ and $0.4 \%$ reduction and improvement, respectively.
\end{abstract}

KeY words: Corn, climate change, climatic risk, fuzzy logic Philippines

Correspondent author:arsalvacion@up.edu.ph

\section{Introduction}

Corn is considered the second most important crop and principal source of income for about 24 million families in the Philippines (Fig. 1) (delos Santos et al. 2007, Gerpacio 2004, Lansigan et al. 2007). According to the report of the Philippine Statistics Authority (PSA-BAS 2015), in the year 2014, around 2.6 M ha of land in the country were planted with corn resulting to 7.7 million tons of corn production with an estimated value of Php 41.3 billion (approximately USD 867 million). Yellow corn in the country is the primary source of material for animal feed industry while white corn serves as important staple substitute for rice (Gerpacio 2004). According to Gerpacio et al. (2004) and delos Santos et al. (2007), corn production losses in the country is mainly due to flood and drought.

Changes in the characteristic and pattern of weather due to climate change are expected to impact agricultural production (Antón et al. 2013, Ewert et al. 2015, Holzkämper et al. 2015, Kim et al. 2016, Ko et al. 2014, Ko, Ahuja 2014). This is due to the fact that agricultural production system is highly sensitive to short-term changes in weather and to seasonal, annual and 


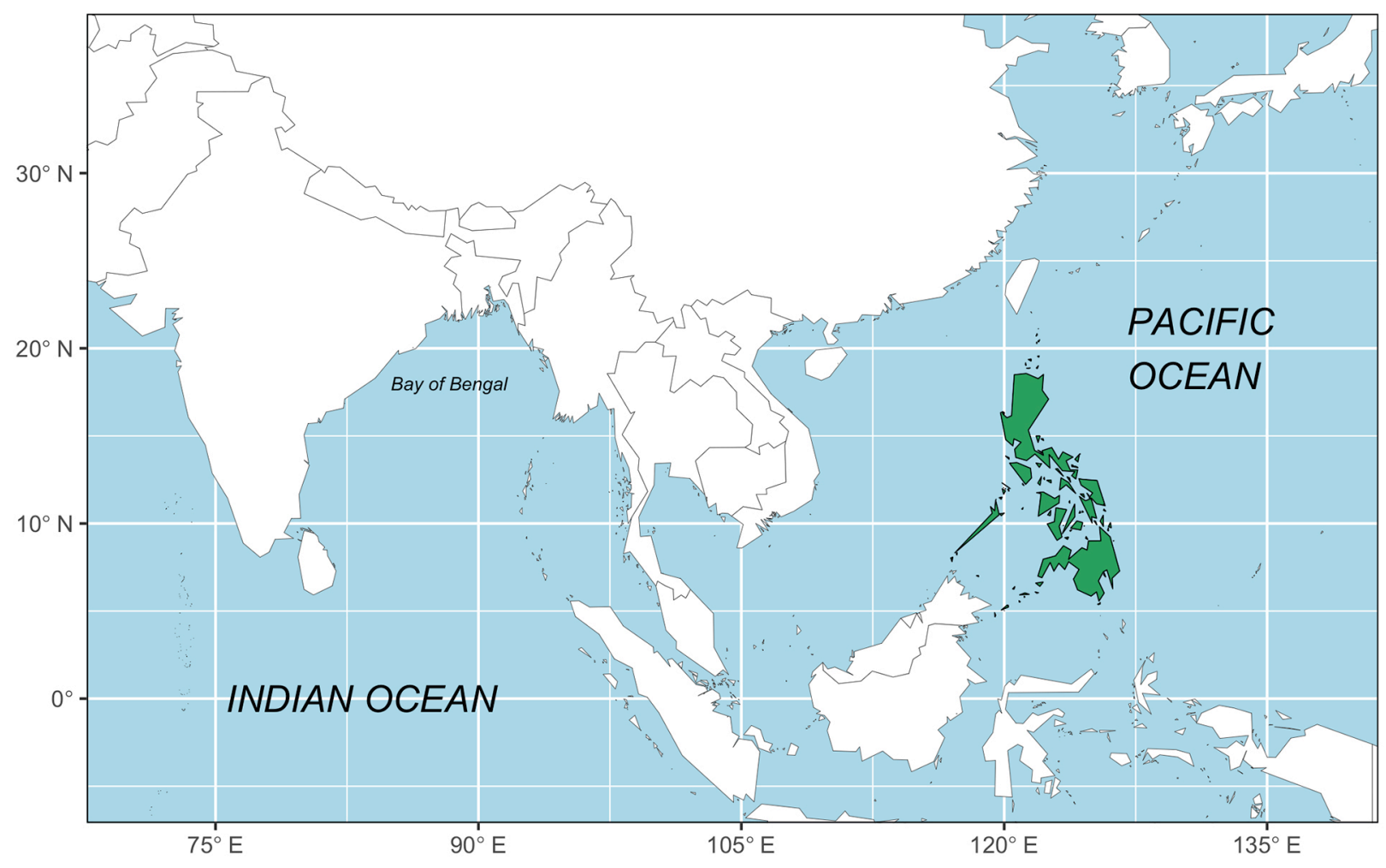

Fig.1. Location map of the Philippines (Data source: R maptool package).

longer term variations in climate (Challinor et al. 2007, Holzkämper et al. 2011, Ray et al. 2015, Sivakumar,Hansen 2007). Direct effects of climate change on agricultural crop production can be divided into two parts. First, climate change affects crop yield because changes in rainfall and temperature affect crop growth and development (Antón et al. 2013, Ewert et al. 2015, Holzkämper et al. 2015, Islam et al. 2012, Kim et al. 2016, Ko et al. 2014, Ko,Ahuja 2014, Yan-Ling et al. 2012). Second, changes on existing climate in an area can alter crop suitability in the region (Bonfante et al. 2015, Chemura et al. 2015, Jayathilaka et al. 2012, Lane, Jarvis 2007, Ovalle-Rivera et al. 2015, Ramirez-Cabral et al. 2016, Wang et al. 2015, Zabel et al. 2014).

Being an agricultural country and located in the tropical region, the Philippines is expected to be highly affected by climatic change (Lansigan, Salvacion 2007). Several studies have already been conducted to assess the impact of climate change on crop yield in the country (Buan et al. 1996, Centeno et al. 1995, Salvacion 2009, 2015). On the other hand, studies conducted to determine the effect climate change on crop suitability in the country are minimal (e.g. Salvacion, Martin 2016).
Different methodological techniques have been developed for evaluating of crop suitability in an area. These techniques ranges from simple approaches based temperature and rainfall during the crop growing period (Hijmans et al. 2003, Ramirez-Villegas et al. 2013) to complex criteria requiring different information on climate and soil or simulation using dynamic crop models (Braimoh et al. 2004, Confalonieri et al. 2013, Hijmans et al. 2003). However, availability of input data limits the adoption of specific technique.

A soft-computing methodology, fuzzy logic provides quick, simple, and sufficient solution while allowing for impreciseness, sub-optimality, and vagueness (Chen, Paydar 2012, de Carvalho Alves et al. 2011, Dubey et al. 2013, Lewis et al. 2014). This makes it flexible and simple to understand, enabling a specialist to easily incorporate his expertise and develop models of complex nonlinear functions (Chen, Paydar 2012, de Carvalho Alves et al. 2011, Dubey et al. 2013, Lewis et al. 2014). Also, other than its ability to combine qualitative and quantitative information, developing model using fuzzy logic can be done without precise quantitative measurements (Kampichler et al. 2000, Kim, Beresford 2011, Salvacion et al. 2015, Scherm 2000). Numerous studies used 
fuzzy logic for crop suitability assessment (e.g. Balezentiene et al. 2013, Braimoh et al. 2004, Joss et al. 2008, Kurtener et al. 2008, Lewis et al. 2014, Papageorgiou et al. 2009, Reshmidevi et al. 2009, Sicat et al. 2005, Triantafilis et al. 2001, Van Ranst et al. 1996, Xiao Zhang and Ximing Cai 2011, Zhao et al. 2015). According to Lewis et at. (2014), continuous membership value (between 1 and 0 ) is assigned for each criterion (e.g. rainfall and temperature) in using fuzzy logic for suitability assessment. Membership values approaching 1 are considered more suitable while membership values approaching zero are considered less suitable.

This paper assesses the spatio-temporal patterns of changes in climatic suitability of corn in the Philippines using fuzzy logic approach and the publicly available WorldClim database (Hijmans et al. 2005) under current and future climate change condition.

\section{Methodology}

\section{Data}

Baseline and future climate condition used in this study were extracted from WorldClim database (Hijmans et al. 2005). WorldClim is a set of global climate surface (climate grids) of monthly precipitation (total) and temperature (minimum, mean, and maximum) with a spatial resolution of about 30 arc-seconds $\left(\sim 1 \mathrm{~km}^{2}\right)$ (Hijmans et al. 2005). Other spatial resolutions of WordClim database include 2.5 arc-minutes $\left(\sim 5 \mathrm{~km}^{2}\right), 5.0$ arc-minutes $\left(\sim 10 \mathrm{~km}^{2}\right)$, and 10 arc-minutes $\left(\sim 20 \mathrm{~km}^{2}\right)$ resolutions. WorldClim baseline climate surfaces were products of interpolating monthly averages of climate, mostly for the period 1950-2000, from different weather stations across the globe (Hijmans et al. 2005) while future climate change conditions were downscaled from most recent Global Circulation Models (GCMs) projection for the year 2050 (average for 2041-2060) and 2070 (average for 2061-2080). WorldClim database (Hijmans et al. 2005) has been widely used for different suitability assessment (e.g. Mighty 2015, Naughton et al. 2015), climate, and climate change impact studies (e.g. Alamgir et al. 2015, Cordovez et al. 2014, Cuervo et al. 2015, Fand et al. 2014, Fischer et al. 2011, Kim, Beresford 2011, Kroschel et al. 2013, Orlandini et al. 2003, Rübbelke, Vögele 2011, Salvacion et al. 2015). In the case of this study, the 2.5 arc-minutes $\left(\sim 5 \mathrm{~km}^{2}\right)$ WorldClim monthly climate surfaces (i.e. rainfall, mean temperature, minimum temperature) were chosen for computational purpose while future climate projections (averaged from 18 GCMs) for RCP 8.5 (Riahi et al. 2011) scenario for the year 2050 (average for 20412060) was used for the assessment.

\section{Fuzzy suitability mapping}

First, fuzzy suitability assessment was done using the climatic parameters (Sys et al. 1993) in Table 1 using fuzzy trapezoidal function for each month of the year as the start of growing period. For example, calculating corn suitability based on rainfall for crop sown during the month of January involved calculation of fuzzy suitability for TRM1 (based on the rainfall during January), TRM2 (based on the rainfall during February), TRM3 (based on the rainfall during March), TRM4 (based on the rainfall during April) and TRGP (based on the total rainfall during the month of January to April). Then, the calculated suitability for each of the rainfall parameters were combined using the weighted sum approach (Table 2) based on the effect of water stress during the crop growing period (Çakir 2004). Higher weights were given to TRM3 and TRM4 because these coincide

Table 1. Climatic parameters for corn suitability assessment adopted from Sys et al. (1993).

\begin{tabular}{|l|c|c|c|c|}
\hline \multicolumn{1}{|c|}{ Parameters } & $\begin{array}{c}\text { Absolute } \\
\text { Minimum }\end{array}$ & $\begin{array}{c}\text { Optimum } \\
\text { Minimum }\end{array}$ & $\begin{array}{c}\text { Optimum } \\
\text { Maximum }\end{array}$ & $\begin{array}{c}\text { Absolute } \\
\text { Maximum }\end{array}$ \\
\hline Total rainfall during the growing period (TRGP) & 300 & 500 & 1200 & 1600 \\
\hline Total rainfall during the first month (TRM1) & 60 & 100 & 295 & 475 \\
\hline Total rainfall during the second month (TRM2) & 70 & 150 & 310 & 475 \\
\hline Total rainfall during the third month (TRM3) & 70 & 150 & 310 & 475 \\
\hline Total rainfall during the fourth month (TRM4) & 60 & 100 & 285 & 475 \\
\hline Average mean temperature during the growing period (AMTP) & 14 & 18 & 32 & 40 \\
\hline Average minimum temperature during the growing period (AMTNP) & 7 & 12 & 24 & 30 \\
\hline
\end{tabular}


Table 2. Weights use for calculating corn suitability based on rainfall.

\begin{tabular}{|c|c|}
\hline Rainfall parameter & Weight \\
\hline TRM1 & 0.10 \\
\hline TRM2 & 0.10 \\
\hline TRM3 & 0.40 \\
\hline TRM4 & 0.30 \\
\hline TRGP & 0.10 \\
\hline
\end{tabular}

with corn growth stages (i.e. tasselling, and ear formation) which is critical to water stress condition (Çakir 2004).

In the case of temperature, fuzzy suitability was calculated based on AMTP parameter using the average mean temperature (AMTP) and average minimum temperature (AMTNP) during the growing period. For example, for corn sown on the month of January, suitability was calculated from the average mean temperature and average minimum temperature from month of January to April. Corn suitability based on temperatures was derived using the minimum between AMTP and AMTNP calculated suitability. Fuzzy suitability for rainfall and temperature was classified into not suitable, marginal, moderate, medium, and high based on the computed fuzzy suitability value (Table 3). Fuzzy suitability calculation based on rainfall and temperature was done both for the baseline and future climate change condition to determine potential changes in suitability due to climate change. Also, suitability changes for rainfall and temperature were considered separate to determine the potential effect of the changes on each variable under future climate change condition.

Fuzzy Suitability $(\mathrm{x}, \mathrm{a}, \mathrm{b}, \mathrm{c}, \mathrm{d})=\left\{\begin{aligned} 0, & x \leq a \\ \frac{x-a}{b-a}, & a \leq x \leq b \\ 1, & b \leq x \leq c \\ \frac{d-x}{d-c,}, & c \leq x \leq d \\ 0, & x \leq d\end{aligned}\right.$

where:

$x$ is climate surface value,

$a$ is the minimum absolute value of the climate parameter,

$b$ is the minimum optimum value of the climate parameter,

$c$ is the maximum optimum value of the climate parameter,

$d$ is the maximum absolute value of the climate parameter.
Table 3. Fuzzy suitability interval used for climatic suitability classification.

\begin{tabular}{|c|c|}
\hline Fuzzy suitability interval & Suitability classification \\
\hline $0.00-0.39$ & Not Suitable \\
\hline $0.40-0.59$ & Marginal \\
\hline $0.60-0.84$ & Moderate \\
\hline $0.85-1.00$ & High \\
\hline
\end{tabular}

\section{Results and Discussion}

\section{Baseline climate condition}

\section{Total monthly rainfall}

Under the baseline climate condition (19502000), total monthly rainfall in the country varies from $2 \mathrm{~mm}$ to $1077 \mathrm{~mm}$. Most part of the country received less than $300 \mathrm{~mm}$ of rainfall during month of December to May, except in southeastern part where the observed rainfall were more than $400 \mathrm{~mm}$. According to the Philippine Atmospheric, Geophysical and Astronomical Services Administration (PAGASA 2017), the month of December to May were considered as the dry season. Meanwhile, during the month of June to November larger portion of the country received higher amount of rainfall $(>300 \mathrm{~mm})$. The month of June to November were considered as the rainy season in the Philippines (PAGASA 2017). Also, most of the typhoons in the country occur during these period (Cinco et al. 2016). Figure 2 shows the monthly spatial distribution of rainfall in the Philippines under baseline climate condition (1950-2000).

\section{Average monthly mean, and minimum temperatures}

The average monthly mean temperature in the Philippines under baseline climate condition ranges from $24.18^{\circ} \mathrm{C}$ (January) to $26.65^{\circ} \mathrm{C}$ (May). Throughout the year, the average monthly mean temperature in the country is above $25^{\circ} \mathrm{C}$ except during the months of December, January, and February. Colder temperature during these months is due to the cold air stream brought by Northeast Moonson (Deppermann 1954). The average monthly minimum temperature shows similar pattern as the average monthly mean temperature. The lowest monthly minimum temperature was calculated during the January $\left(20.02^{\circ} \mathrm{C}\right)$ while the highest was calculated for the month of May $\left(22.18^{\circ} \mathrm{C}\right)$. Meanwhile, distinct lower 

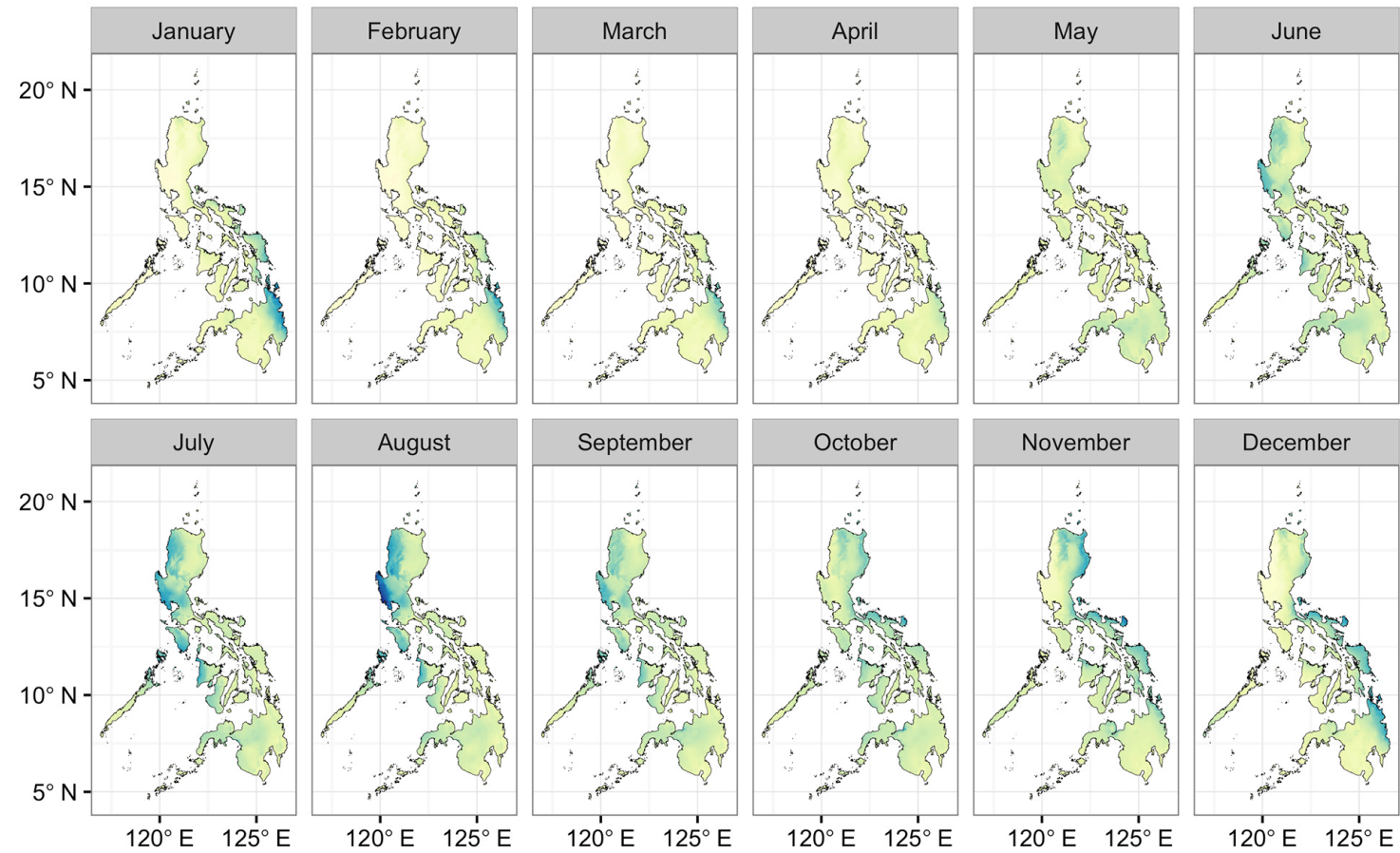

Baseline Average Total Monthly Rainfall (mm)

$\begin{array}{llllll}0 & 200 & 400 & 600 & 800 & 1000\end{array}$

Fig. 2. Spatial distribution of average total monthly rainfall in the Philippines under baseline climate condition (1950-2000).
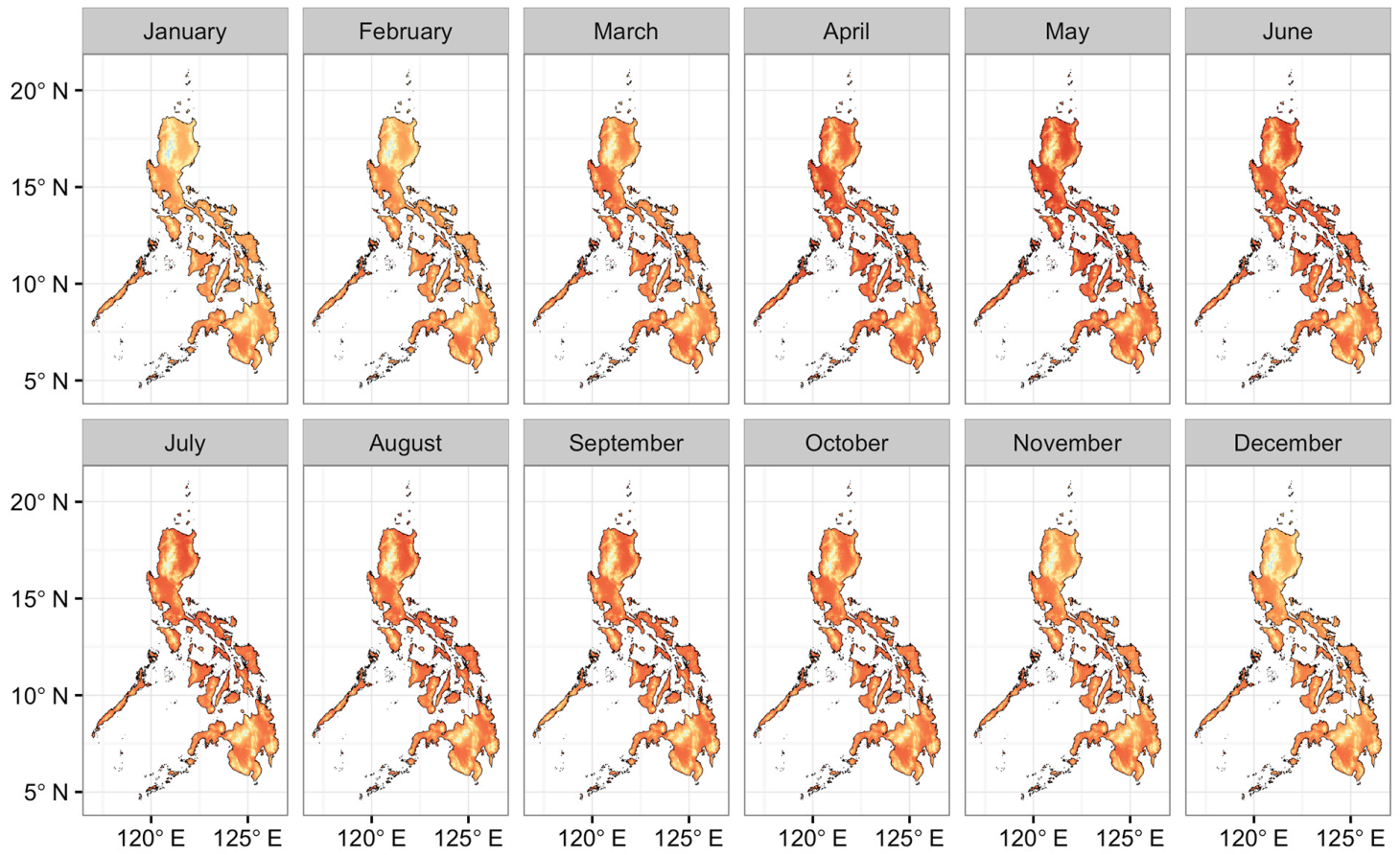

Baseline Monthly Average Mean Temperature $\left({ }^{\circ} \mathrm{C}\right)$

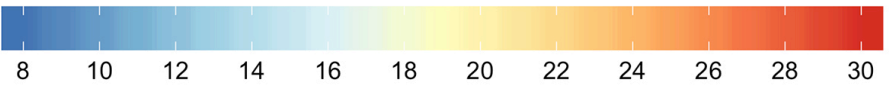

Fig. 3. Spatial distribution of average mean monthly temperature in the Philippines under baseline climate condition (1950-2000). 

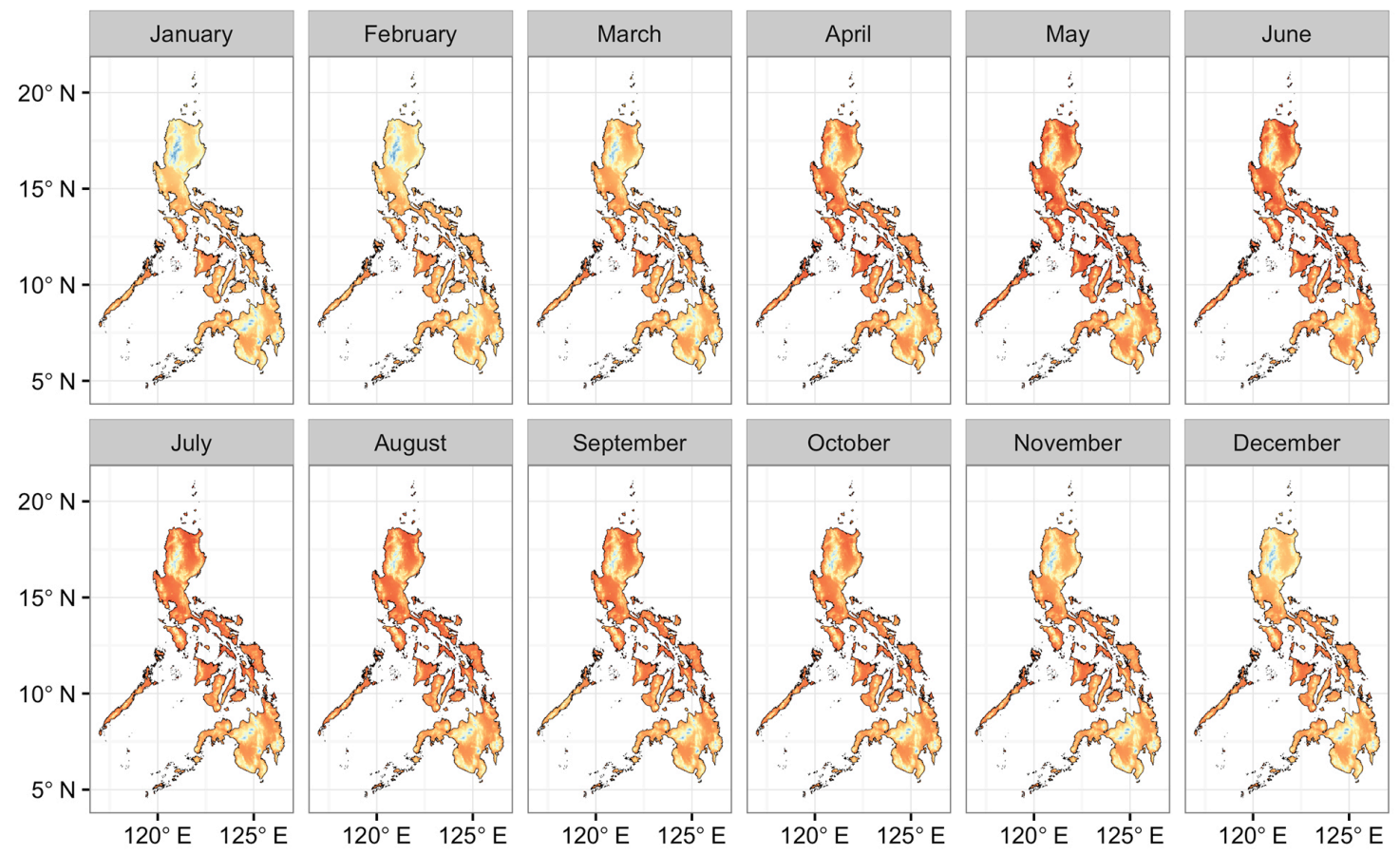

Baseline Monthly Average Minimum Temperature $\left({ }^{\circ} \mathrm{C}\right)$

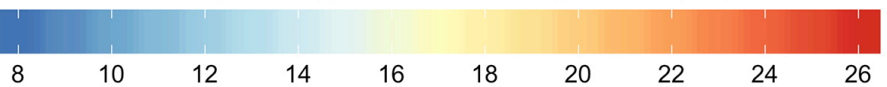

Fig. 4. Spatial distribution of average minimum monthly temperature in the Philippines under baseline climate condition (1950-2000).
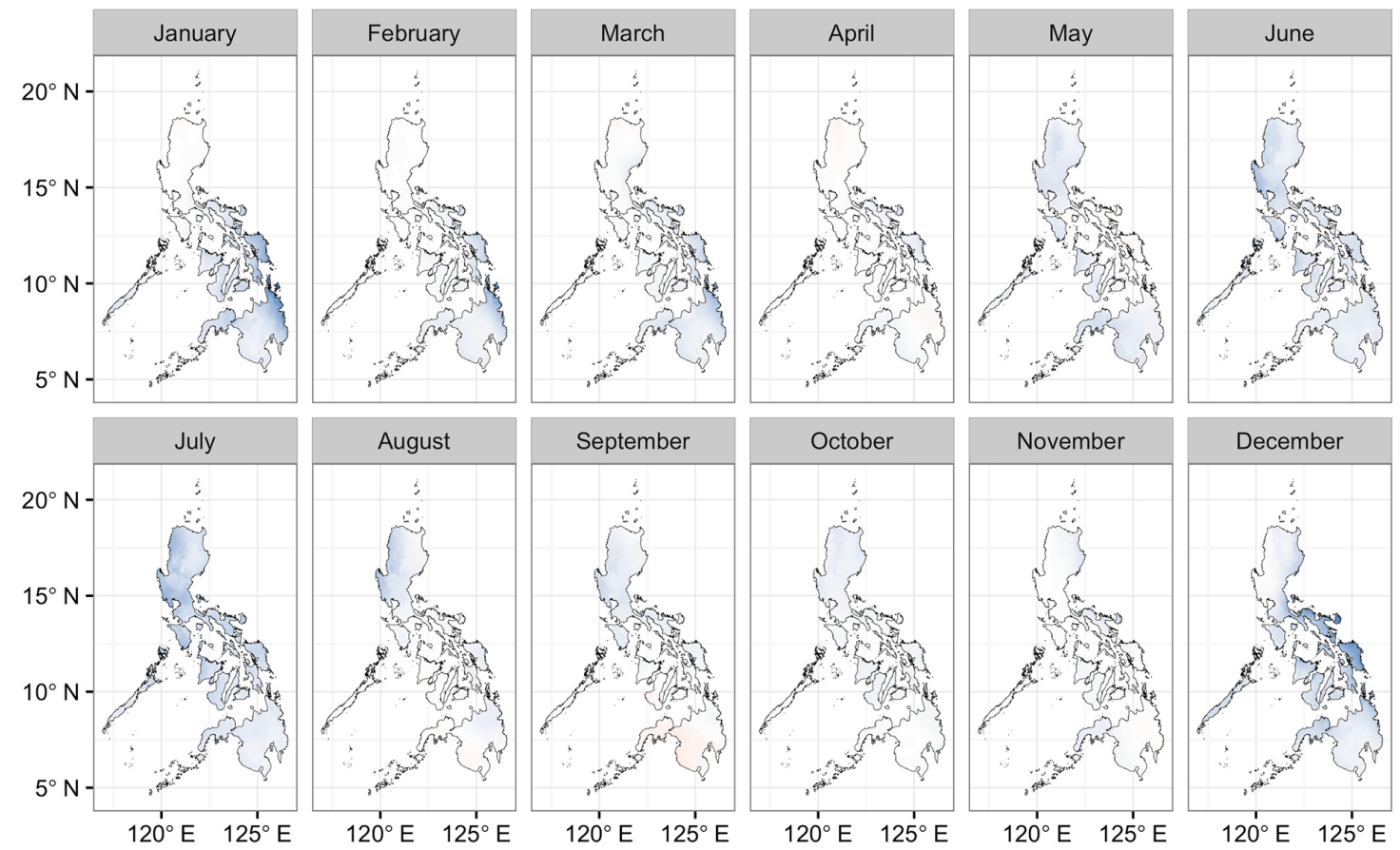

Projected Changes in Average Total Monthly Rainfall ( $\mathrm{mm})$

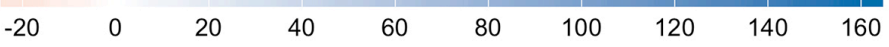

Fig. 5. Spatial distribution of projected changes in average total monthly rainfall in the Philippines under future climate condition (2041-2060). 
temperature can be observed in the mountainous portion of the northwestern part country during the months of January and February. According to Jose et al. (1996) elevation highly influence temperature in country. Colder temperatures were observed on higher elevation compared to those in the low-lying areas. Figures 3 and 4 show the monthly spatial distribution of average monthly mean, and minimum temperature.

\section{Projected changes in climate}

\section{Changes in total monthly rainfall}

Total monthly rainfall is expected to change across the country under future climate condition. The magnitude of change varies across location and months (Fig. 5). Large portion (88\%) of the country is projected to experience increase in rainfall. From the month January to March, increases in rainfall were projected on the central and southern portion of the country. On the average, projected increase during these months were $24 \mathrm{~mm}, 12 \mathrm{~mm}$, and $14 \mathrm{~mm}$, respectively. However, higher spatial variation in the change in rainfall was observed during January $(-11 \mathrm{~mm}$ to $154 \mathrm{~mm}$ ) compared to February ( $-7 \mathrm{~mm}$ to 117 $\mathrm{mm})$ and March (-8mm to $92 \mathrm{~mm})$. For the month of April, minimal change in rainfall was observed for most part of the country. The projected change in rainfall during this month ranges from $-9 \mathrm{~mm}$ to $29 \mathrm{~mm}$ with mean of $2 \mathrm{~mm}$. For the months of May to July, increase in rainfall is projected for almost the entire country. During these months, the average increases in rainfall were around 15 $\mathrm{mm}, 22 \mathrm{~mm}$, and $30 \mathrm{~mm}$, respectively. Higher spatial variation in the projected increase in rainfall was observed for the month of July $(7 \mathrm{~mm}$ to $81 \mathrm{~mm})$ compared to June $(6 \mathrm{~mm}$ to $72 \mathrm{~mm})$ and May ( $-7 \mathrm{~mm}$ to $37 \mathrm{~mm})$. For the month of August and September, increase in rainfall is projected for almost the entire Philippines, except on the southwestern part. Projected maximum decreases in rainfall during these months were around -10 $\mathrm{mm}$ and $-20 \mathrm{~mm}$, respectively. For the month of October and November, increases in rainfall were observed only on the northern and central portion of the country. Increases in monthly total rainfall in the country during these ranges from $0.05 \mathrm{~mm}$ to $24 \mathrm{~mm}$, and $0.05 \mathrm{~mm}$ to $43 \mathrm{~mm}$, respectively. For the month of December, increase in rainfall was projected for the entire country, ranging from
$0.11 \mathrm{~mm}$ to $145 \mathrm{~mm}$. Higher increase in rainfall were observed on the eastern portion. Historical changes in rainfall has been observed in the country based on weather station records (Cinco et al. 2014). However, although increase in trends was observed for intensity and frequency of extreme rainfall events for most weather stations in the country, a small portion of these station shows statistically significant trend (Cinco et al. 2014).

\section{Changes in average monthly mean temperature}

Average monthly mean temperature is projected to increase for the entire country under future climate condition. Similar to rainfall, increase in average monthly mean temperature varies across location and month (Fig. 6). Higher increases in average monthly mean temperature were projected on the eastern portion of the country during the months of October to February while on the western portion of the country; these were projected during the months of June to September. The highest increase in temperature $\left(7.2^{\circ} \mathrm{C}\right)$ was projected on the western portion of the country during the month of August. According to Cinco et al. (2014), mean temperature in the country consistently rises since the 1978 with observed anomalies reaching $0.1^{\circ} \mathrm{C}$ to $1.0^{\circ} \mathrm{C}$ in the $1990^{\prime}$ s. However, the range is projected to increase with monthly mean temperature in the country reaching more than $1.5^{\circ} \mathrm{C}$ during the month of May to December in the future.

\section{Changes in average monthly minimum temperature}

Spatial and temporal (Fig. 7) pattern of increase in average monthly minimum temperature in the Philippines resembles similar pattern as the increase in average monthly mean temperature. This is due to the fact that average monthly mean temperature is derived from the average monthly minimum temperature and average monthly maximum temperature. However, it can be noted that higher increase in average monthly minimum temperature is projected under future climate condition. On the average, increase in monthly minimum temperature during the month of August to November is more than $2^{\circ} \mathrm{C}$; with the highest projected temperature $\left(7.4^{\circ} \mathrm{C}\right)$ observed during the month of August. An increase more than $0.5^{\circ} \mathrm{C}$ in minimum temperature was observed in the country at the start of the 21st 

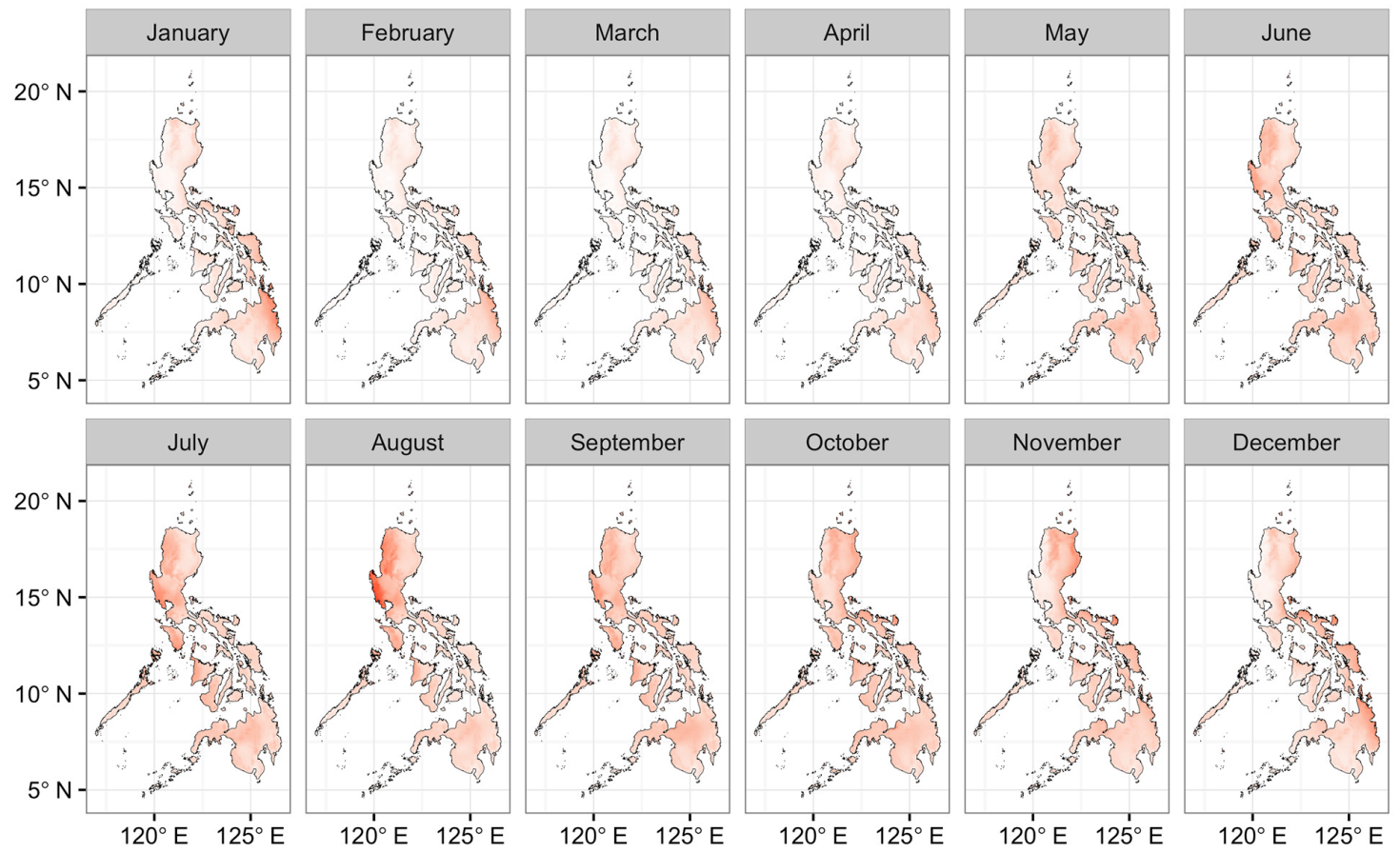

Projected Change in Monthly Average Mean Temperature $\left({ }^{\circ} \mathrm{C}\right)$

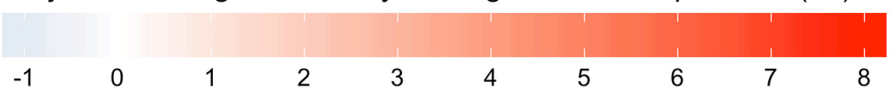

Fig. 6. Spatial distribution of projected changes in monthly average mean temperature in the Philippines under future climate condition (2041-2060).
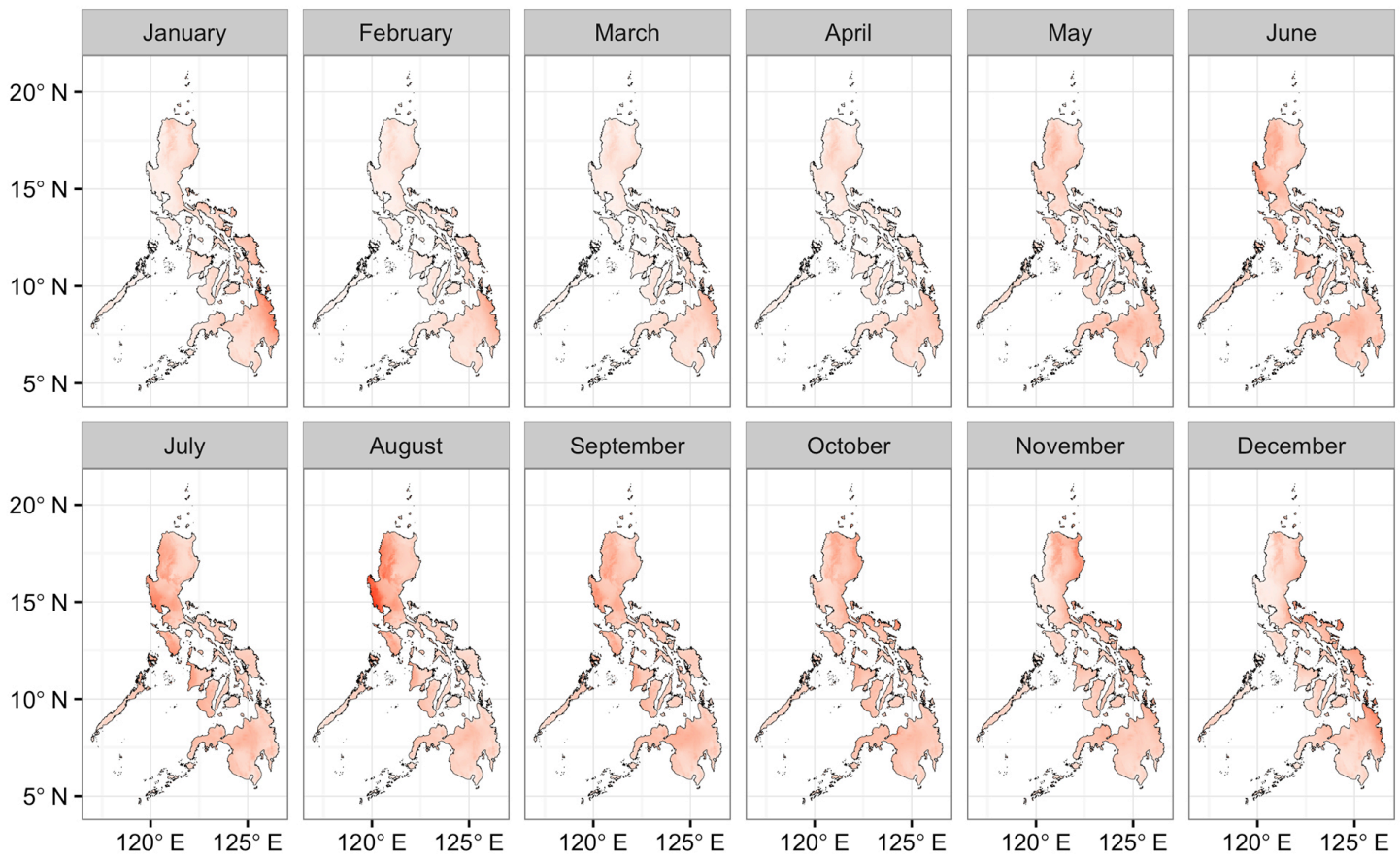

Projected Change in Monthly Average Minimum Temperature $\left({ }^{\circ} \mathrm{C}\right)$

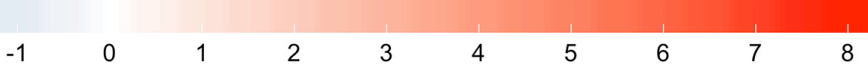

Fig. 7. Spatial distribution of projected changes in monthly average minimum temperature in the Philippines under future climate condition (2041-2060). 
century while the highest increase in minimum temperature $\left(1^{\circ} \mathrm{C}\right)$ in the country was observed during the 1997-1998 period (Cinco et al. 2014).

\section{Projected change in corn climatic suitability}

\section{Rainfall Suitability}

The effect of projected changes in total monthly rainfall on corn suitability (Fig. 8) in the country under future climate condition also varies across months and location (Fig. 9). However, only small portion of the country are projected to have either improve $(6 \%)$ or reduce $(8 \%)$ rainfall suitability
(Table 4). Out of these small portions with projected changes in rainfall suitability, higher percentage of decline was observed in most months of the year (8 out of 12). The highest proportion of decline in rainfall suitability was calculated for the months of April (17\%). During this month, Marginal to Not Suitable (4.4\%) and Moderate to Marginal $(3.8 \%)$ changes in suitability were projected on the middle north and northeastern part of while High to Moderate $(8.8 \%)$ changes in rainfall suitability were projected on the other part of the northeast, central, and to southeastern portion. Meanwhile, there is higher percentage of areas with improved suitability versus areas with declined suitability projected during the months
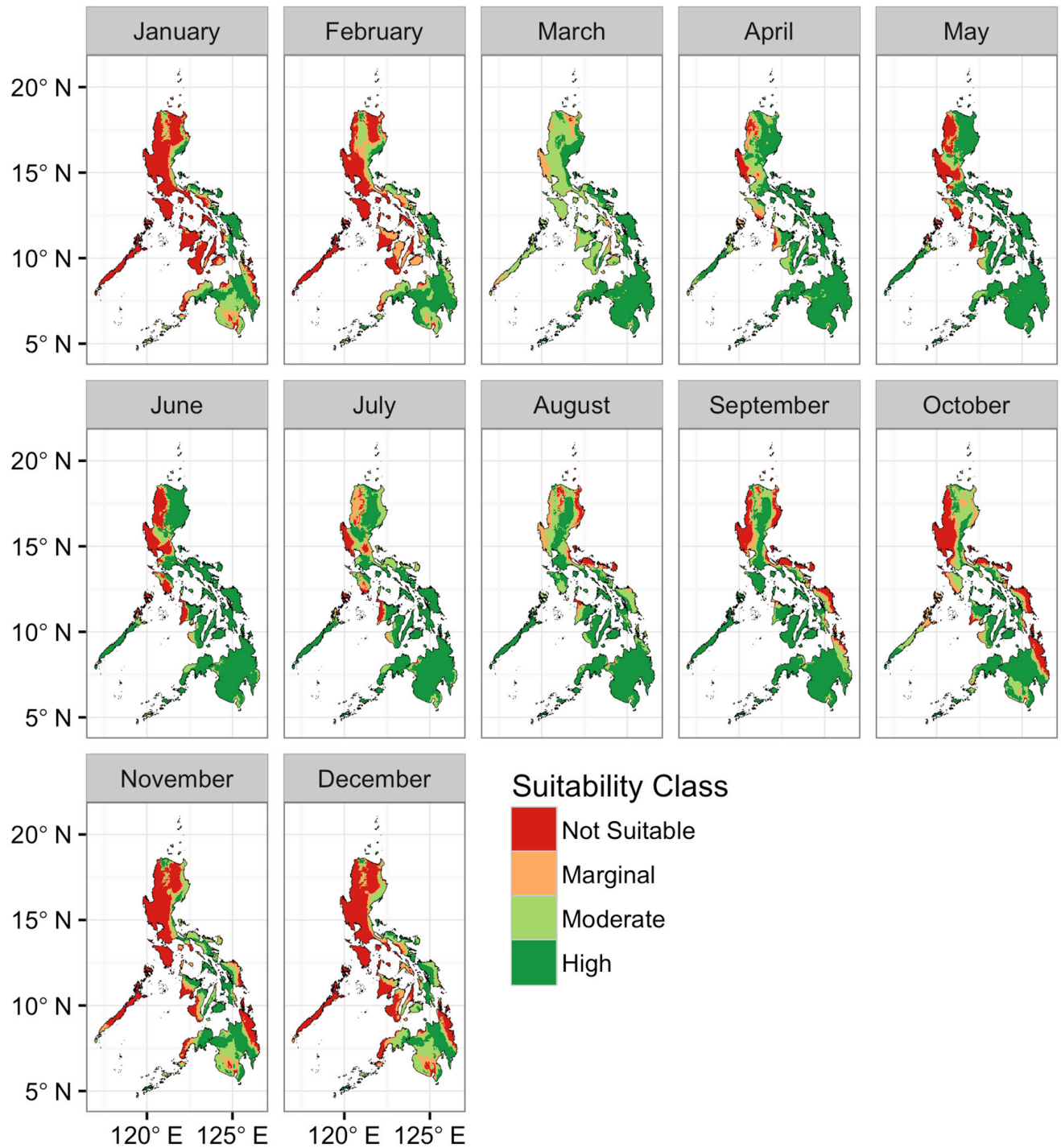

Fig. 8. Monthly spatial distribution of climatic suitability of corn based on rainfall in the Philippines under baseline condition. 

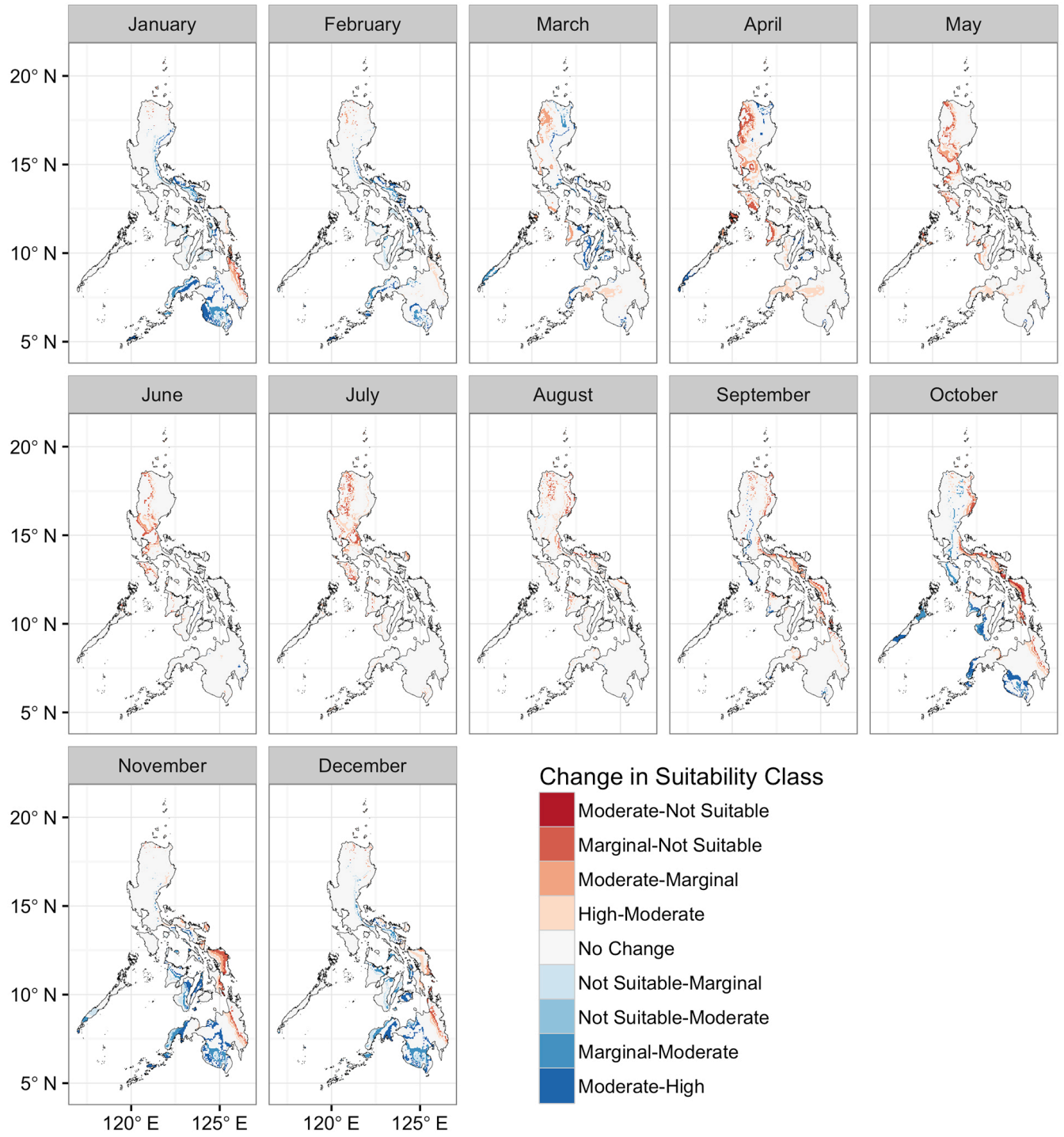

Fig. 9. Monthly spatial distribution of changes in climatic suitability of corn based on rainfall in the Philippines under future climate condition.

of November to February. The highest percentage of improvement in suitability was calculated during the month of December (15.2\%). During this month, improvements in climatic suitability based on rainfall were projected on the mid central and southwestern portion of the country such as Not Suitable to Marginal (4.3\%), Not Suitable to Moderate $(0.1 \%)$, from Marginal to Moderate $(6.1 \%)$, and from Moderate to High (4.68\%). The projected increases in rainfall in the country under future climate condition alter the suitability of corn production in the most part of the country because excessive water affects corn at every growth stage (Kuang et al. 2012, Zaidi et al. 2004). According to Zaidi et al. (2004), excessive moisture condition at all physiological stages results to plant mortality, stunted growth, and reduced leaf area and total biomass. Based on the study of Kuang et al. (2012), excess water or flooding during the seedling, jointing, tasseling to silking, and maturity stage results to $25.8-67.1 \%, 26.1-34.7 \%, 10.8-25.0 \%$, and $3.1-$ $4.9 \%$ reduction in yield, respectively.

\section{Temperature Suitability}

Under baseline climate condition (1950-2000), temperature (average monthly mean and minimum) does impose serious limitation on corn suitability in the country except on some areas (Fig. 10) situated in high elevation where temperature is below the optimum level for corn growth 
Table 4. Monthly proportion (\%) of changes in climatic suitability due to change in rainfall under future climate condition.

\begin{tabular}{|l|c|c|c|c|c|c|c|c|c|}
\hline \multicolumn{1}{|c|}{ Month } & $\begin{array}{c}\text { Moderate- } \\
\text { Not } \\
\text { Suitable }\end{array}$ & $\begin{array}{c}\text { Marginal- } \\
\text { Not } \\
\text { Suitable }\end{array}$ & $\begin{array}{c}\text { Moderate- } \\
\text { Marginal }\end{array}$ & $\begin{array}{c}\text { High- } \\
\text { Moderate }\end{array}$ & $\begin{array}{c}\text { No } \\
\text { Change }\end{array}$ & $\begin{array}{c}\text { Not } \\
\text { Suitable- } \\
\text { Marginal }\end{array}$ & $\begin{array}{c}\text { Not } \\
\text { Suitable- } \\
\text { Moderate }\end{array}$ & $\begin{array}{c}\text { Marginal- } \\
\text { Moderate }\end{array}$ & $\begin{array}{c}\text { Moderate- } \\
\text { High }\end{array}$ \\
\hline January & 0.0 & 1.1 & 1.3 & 1.4 & 81.6 & 4.1 & 0.0 & 4.8 & 5.8 \\
\hline February & 0.0 & 0.1 & 0.5 & 1.4 & 89.4 & 2.9 & 0.0 & 2.8 & 3.0 \\
\hline March & 0.0 & 0.0 & 3.5 & 3.6 & 86.6 & 0.1 & 0.0 & 2.7 & 3.5 \\
\hline April & 0.0 & 4.4 & 3.8 & 8.8 & 80.6 & 0.0 & 0.0 & 0.1 & 2.3 \\
\hline May & 0.0 & 3.0 & 3.4 & 4.5 & 88.9 & 0.0 & 0.0 & 0.0 & 0.2 \\
\hline June & 0.0 & 1.9 & 2.1 & 1.8 & 93.9 & 0.0 & 0.0 & 0.0 & 0.2 \\
\hline July & 0.0 & 2.4 & 3.1 & 3.9 & 90.6 & 0.0 & 0.0 & 0.0 & 0.0 \\
\hline August & 0.0 & 1.6 & 1.8 & 3.3 & 93.1 & 0.0 & 0.0 & 0.1 & 0.1 \\
\hline September & 0.0 & 2.5 & 3.1 & 3.2 & 90.0 & 0.0 & 0.0 & 0.3 & 1.0 \\
\hline October & 0.6 & 3.1 & 3.4 & 4.0 & 78.6 & 1.1 & 0.0 & 3.8 & 5.5 \\
\hline November & 0.2 & 2.2 & 2.2 & 3.4 & 77.3 & 3.2 & 0.2 & 4.5 & 6.8 \\
\hline December & 0.0 & 1.1 & 1.5 & 2.7 & 79.5 & 4.3 & 0.1 & 6.1 & 4.8 \\
\hline
\end{tabular}
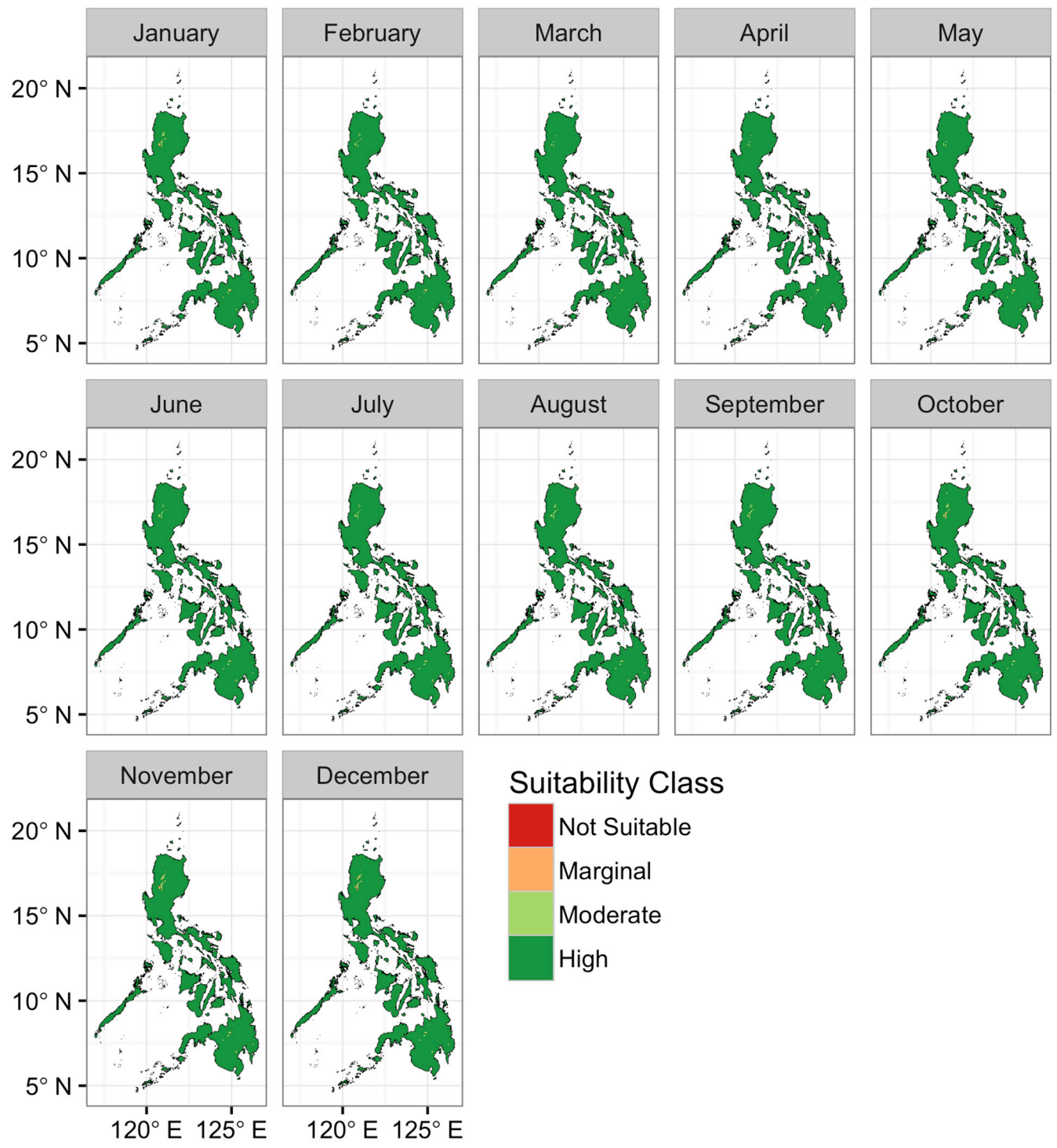

Fig. 10. Monthly spatial distribution of climatic suitability of corn based on temperature in the Philippines under baseline condition. 
and development. Under future climate condition, the increases in temperature in the country reduce suitability of corn from High to Marginal, and High to Medium during the months of April to July on the northeast and eastern portion of the country (Fig. 11). The highest proportion of areas with reduce suitability was projected for the month of June (15.1\%). In addition, there were more months (10 out of 12) where the proportion of areas with reduce suitability (5\%) is higher than those with improved suitability $(0.4 \%)$. On the average, Increase in ambient temperature affects corn physiological processes and accelerates the rate of its development resulting to early maturity, which leads to lesser biomass accumulation, thus reducing yield (Brown, Rosenberg 1999, Challinor et al. 2004, Meza et al. 2008). Meanwhile, improvements in suitability were projected on those high elevation areas of the county. Empirical study of Chen et al. (2011) showed that increase in minimum temperature can also be favorable to corn yield. Table 5 summarizes the monthly proportion of changes in climatic suitability of corn based on temperature.

\section{Summary and Conclusion}

This study demonstrated the use of fuzzy logic for spatio-temporal mapping of climatic
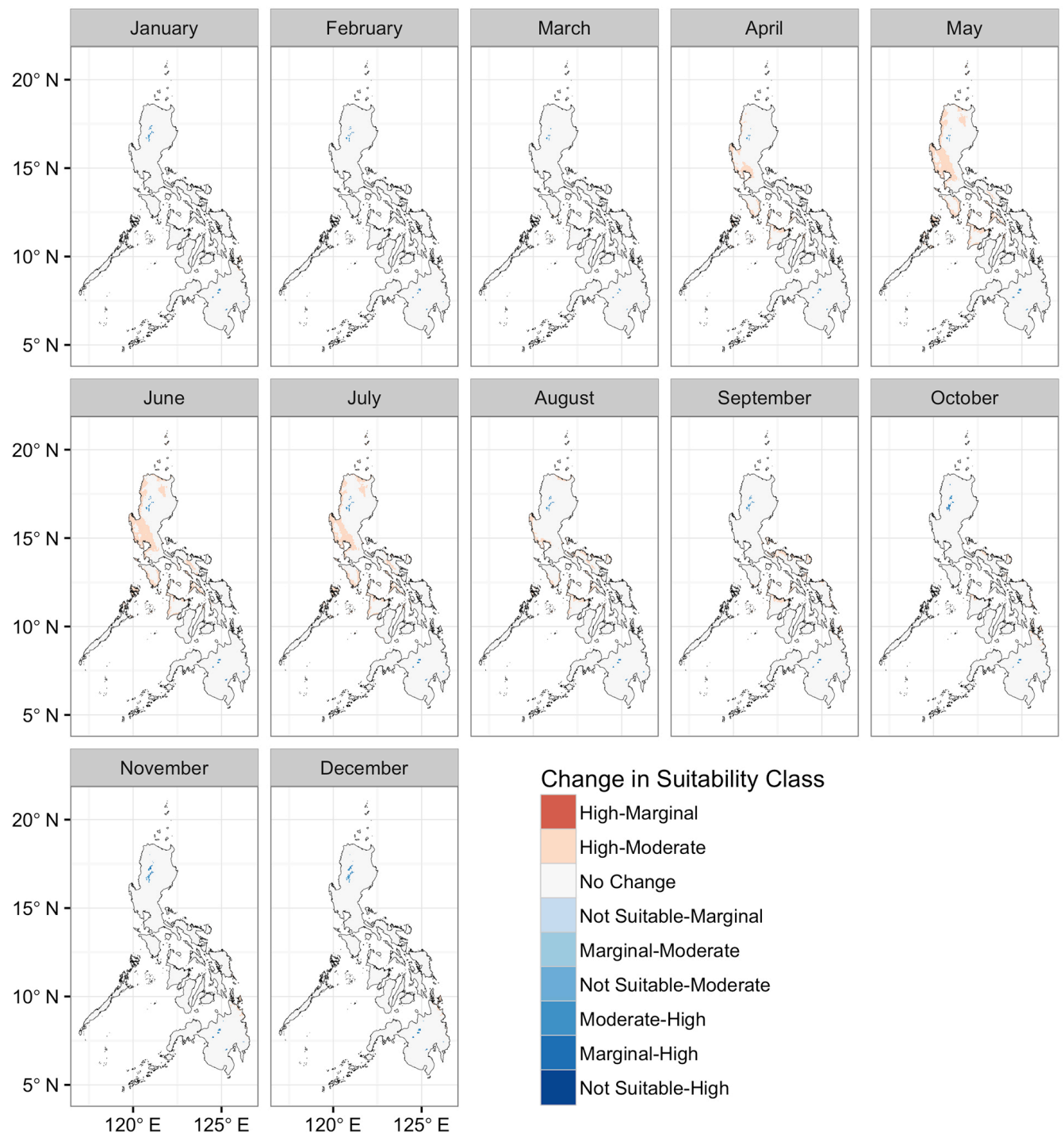

Fig. 11. Monthly spatial distribution of changes in climatic suitability of corn based on temperature in the Philippines under future climate condition. 
Table 5. Monthly proportion (\%) of changes in climatic suitability due to change in temperature under future climate condition.

\begin{tabular}{|l|c|c|c|c|c|c|c|c|c|}
\hline \multicolumn{1}{|c|}{ Month } & $\begin{array}{c}\text { High- } \\
\text { Marginal }\end{array}$ & $\begin{array}{c}\text { High- } \\
\text { Moderate }\end{array}$ & $\begin{array}{c}\text { No } \\
\text { Change }\end{array}$ & $\begin{array}{c}\text { Not } \\
\text { Suitable- } \\
\text { Marginal }\end{array}$ & $\begin{array}{c}\text { Marginal- } \\
\text { Moderate }\end{array}$ & $\begin{array}{c}\text { Not } \\
\text { Suitable- } \\
\text { Moderate }\end{array}$ & $\begin{array}{c}\text { Moderate- } \\
\text { High }\end{array}$ & $\begin{array}{c}\text { Marginal- } \\
\text { High }\end{array}$ & $\begin{array}{c}\text { Not } \\
\text { Suitable- } \\
\text { High }\end{array}$ \\
\hline January & 0.0 & 0.3 & 99.3 & 0.0 & 0.1 & 0.0 & 0.3 & 0.0 & 0.0 \\
\hline February & 0.0 & 0.1 & 99.7 & 0.0 & 0.0 & 0.0 & 0.2 & 0.0 & 0.0 \\
\hline March & 0.0 & 0.3 & 99.5 & 0.0 & 0.0 & 0.0 & 0.2 & 0.0 & 0.0 \\
\hline April & 0.0 & 6.3 & 93.5 & 0.0 & 0.0 & 0.0 & 0.2 & 0.0 & 0.0 \\
\hline May & 0.0 & 14.4 & 85.4 & 0.0 & 0.0 & 0.0 & 0.2 & 0.0 & 0.0 \\
\hline June & 0.1 & 15.0 & 84.6 & 0.0 & 0.0 & 0.0 & 0.3 & 0.0 & 0.0 \\
\hline July & 0.0 & 13.3 & 86.4 & 0.0 & 0.0 & 0.0 & 0.3 & 0.0 & 0.0 \\
\hline August & 0.0 & 6.4 & 93.2 & 0.0 & 0.0 & 0.0 & 0.3 & 0.1 & 0.0 \\
\hline September & 0.0 & 4.4 & 95.2 & 0.0 & 0.0 & 0.0 & 0.3 & 0.1 & 0.0 \\
\hline October & 0.0 & 2.2 & 97.4 & 0.0 & 0.0 & 0.0 & 0.4 & 0.1 & 0.0 \\
\hline November & 0.0 & 0.9 & 98.5 & 0.0 & 0.1 & 0.0 & 0.4 & 0.1 & 0.0 \\
\hline December & 0.0 & 0.6 & 98.8 & 0.0 & 0.1 & 0.0 & 0.4 & 0.1 & 0.0 \\
\hline
\end{tabular}

suitability of corn production in the Philippines under baseline and future climate change condition utilizing publicly available baseline and future climatic data. Based on the result of the study, spatio-temporal pattern of changes in rainfall and temperatures (mean and minimum) is projected for the Philippines under future climate condition. Most part of the country is projected to experience increase rainfall and temperatures, which results in changes in climatic suitability of corn in some parts of the country. The effect of increased rainfall and temperature to climatic suitability under future climate condition varies across location and months. However, the effect of increase in temperature resulted to higher proportion of areas and months with reduced climatic suitability.

The result of this study conforms with the previous study conducted by Salvacion and Martin (2016) where changes in rainfall and temperature resulted to decrease in climatic suitability of corn in the province of Isabela, Philippines. In addition, it also agrees with different studies elsewhere that the effect of climate change on suitability varies across area (Bonfante et al. 2015, Chemura et al. 2015, Jayathilaka et al. 2012, Lane, Jarvis 2007, Ovalle-Rivera et al. 2015, RamirezCabral et al. 2016, Wang et al. 2015, Zabel et al. 2014). On the other hand, it also shows that the effect of climate change on crop suitability varies across time (months) or depending on the start of cropping period.

The result from this study can serve as an indicator not only how climate change can alter associated climatic suitability of corn in the country but as well as the total corn production (since production is a function of yield and area harvested). In addition, the methodology used in the study can also be used with other major crops (e.g. rice, coconut, banana, etc.) grown in the country and assess impact of climate change on these crops. On the other hand, an in-depth study incorporating other physical parameters (i.e. soil texture, land forms) and actual corn production or harvested map of the country, which are not available during the conduct of the study, is highly recommended to have a complete picture of the impact of climate change on corn production in the Philippines.

\section{References}

Alamgir M., Mukul S.A., Turton S.M., 2015. Modelling spatial distribution of critically endangered Asian elephant and Hoolock gibbon in Bangladesh forest ecosystems under a changing climate. Applied Geography 60: 10-19. doi: 10.1016/j.apgeog.2015.03.001.

Antón J., Cattaneo A., Kimura S., Lankoski J., 2013. Agricultural risk management policies under climate uncertainty. Global Environmental Change 23(6): 1726-1736. doi: 10.1016/j.gloenvcha.2013.08.007.

Balezentiene L., Streimikiene D., Balezentis T., 2013. Fuzzy decision support methodology for sustainable energy crop selection. Renewable and Sustainable Energy Reviews 17: 83-93. doi: 10.1016/j.rser.2012.09.016.

Bonfante A., Monaco E., Alfieri S.M., De Lorenzi F., Manna P., Basile A., Bouma J., 2015. Chapter Two - Climate Change Effects on the Suitability of an Agricultural Area to Maize Cultivation: Application of a New Hybrid Land Evaluation System, in: Donald L. Sparks (Ed.), Advances in Agronomy. Academic Press, pp. 33-69. 
Braimoh A.K., Vlek P.L.G., Stein A., 2004. Land Evaluation for Maize Based on Fuzzy Set and Interpolation. Environmental Management 33(2): 226-238. doi: 10.1007/s00267003-0171-6.

Brown R., Rosenberg N., 1999. Climate Change Impacts on the Potential Productivity of Corn and Winter Wheat in Their Primary United States Growing Regions. Climatic Change 41(1): 73-107. doi: 10.1023/ A:1005449132633.

Buan R.D., Maglinao A.R., Evangelista P.P., Pajuelas B.G., 1996. Vulnerability of rice and corn to climate change in the Philippines. Water, Air, and Soil Pollution 92(1-2): 41-51. doi: 10.1007/BF00175551.

Çakir R., 2004. Effect of water stress at different development stages on vegetative and reproductive growth of corn. Field Crops Research 89(1): 1-16. doi: 10.1016/j. fcr.2004.01.005.

Centeno H., Balbarez A., Fabellar N., Kropff M., Matthews R., 1995. Production in the Philippines under current and future climates, in: Modeling the Impact of Climate Change on Rice Production in Asia. CAB International, pp. 237-250.

Challinor A.J., Wheeler T.R., Craufurd P.Q., Slingo J.M., Grimes D.I.F., 2004. Design and optimisation of a large-area process-based model for annual crops. Agricultural and Forest Meteorology 124(1-2): 99-120. doi:10.1016/j. agrformet.2004.01.002

Challinor A., Wheeler T., Garforth C., Craufurd P., Kassam A., 2007. Assessing the vulnerability of food crop systems in Africa to climate change. Climatic Change 83(3): 381-399. doi: 10.1007/s10584-007-9249-0.

Chemura A., Kutywayo D., Chidoko P., Mahoya C., 2015. Bioclimatic modelling of current and projected climatic suitability of coffee (Coffea arabica) production in Zimbabwe. Regional Environmental Change 16(2): 473-485. doi: 10.1007/s10113-015-0762-9.

Chen C., Lei C., Deng A., Qian C., Hoogmoed W., Zhang W., 2011. Will higher minimum temperatures increase corn production in Northeast China? An analysis of historical data over 1965-2008. Agricultural and Forest Meteorology 151(12): 1580-1588. doi: 10.1016/j.agrformet.2011.06.013.

Chen Y., Paydar Z., 2012. Evaluation of potential irrigation expansion using a spatial fuzzy multi-criteria decision framework. Environmental Modelling \& Software 38: 147157. doi: 10.1016/j.envsoft.2012.05.010.

Cinco T.A., de Guzman R.G., Hilario F.D., Wilson D., 2014. Long-term trends and extremes in observed daily precipitation and near surface air temperature in the Philippines for the period 1951-2010. Atmospheric Research 145-146: 12-26. doi: 10.1016/j.atmosres.2014.03.025.

Cinco T.A., de Guzman R.G., Ortiz A.M.D., Delfino R.J.P., Lasco R.D., Hilario F.D., Juanillo E.L., Barba R., Ares E.D., 2016. Observed trends and impacts of tropical cyclones in the Philippines. International Journal of Climatology 36(14): 4638-4650. doi: 10.1002/joc.4659.

Confalonieri R., Francone C., Cappelli G., Stella T., Frasso N., Carpani M., Bregaglio S., Acutis M., Tubiello F.N., Fernandes E., 2013. A multi-approach software library for estimating crop suitability to environment. Computers and Electronics in Agriculture 90: 170-175. doi: 10.1016/j. compag.2012.09.016.

Cordovez J.M., Rendon L.M., Gonzalez C., Guhl F., 2014. Using the basic reproduction number to assess the effects of climate change in the risk of Chagas disease transmission in Colombia. Acta Tropica 129: 74-82. doi: 10.1016/j.actatropica.2013.10.003.
Cuervo P.F., Rinaldi L., Cringoli G., 2015. Modeling the extrinsic incubation of Dirofilaria immitis in South America based on monthly and continuous climatic data. Veterinary Parasitology 209(1-2): 70-75. doi: 10.1016/j. vetpar.2015.02.010.

de Carvalho Alves M., Pozza E.A., Sanches L., de Carvalho L.G., 2011. Fuzzy Logic System Modeling Soybean Rust Monocyclic Process. INTECH Open Access Publisher.

elos Santos W., Lansigan F., Hansen J., 2007. Linking Corn Production, Climate Information and Farm-Level Decision-Making: A Case Study in Isabela, Philippines, in: Climate Prediction and Agriculture. pp. 157-164.

Deppermann C.E., 1954. General features of Philippine Weather. Philippine Studies 2(2): 102-125.

Dubey S., Pandey R.K., Gautam S.S., 2013. Literature treview on fuzzy expert system in agriculture. International Journal of Soft Computing and Engineering 2(6): 289-291.

Ewert F., Rötter R.P., Bindi M., Webber H., Trnka M., Kersebaum K.C., Olesen J.E., van Ittersum M.K., Janssen S., Rivington M., Semenov M.A., Wallach D., Porter J.R., Stewart D., Verhagen J., Gaiser T., Palosuo T., Tao F., Nendel C., Roggero P.P., Bartošová L., Asseng S., 2015. Crop modelling for integrated assessment of risk to food production from climate change. Environmental Modelling $\mathcal{E}$ Software 72: 287-303. doi: 10.1016/j.envsoft.2014.12.003.

Fand B.B., Tonnang H.E.Z., Kumar M., Bal S.K., Singh N.P., Rao D.V.K.N., Kamble A.L., Nangare D.D., Minhas P.S., 2014. Predicting the impact of climate change on regional and seasonal abundance of the mealybug Phenacoccus solenopsis Tinsley (Hemiptera: Pseudococcidae) using temperature-driven phenology model linked to GIS. Ecological Modelling 288: 62-78. doi: 10.1016/j.ecolmodel.2014.05.018.

Fischer D., Thomas S.M., Niemitz F., Reineking B., Beierkuhnlein C., 2011. Projection of climatic suitability for Aedes albopictus Skuse (Culicidae) in Europe under climate change conditions. Global and Planetary Change 78(1-2): 54-64. doi: 10.1016/j.gloplacha.2011.05.008.

Gerpacio R.V., 2004. Maize in the Philippines: production systems, constraints, and research priorities. International Fund for Agricultural Development, International Maize and Wheat Improvement Center, Mexico, D.F., Mexico.

Hijmans R.J., Cameron S.E., Parra J.L., Jones P.G., Jarvis A., 2005. Very high resolution interpolated climate surfaces for global land areas. International Journal of Climatology 25(15): 1965-1978. doi: 10.1002/joc.1276. (http://www. worldclim.org)

Hijmans R.J., Condori B., Carrillo R., Kropff M., 2003. A quantitative and constraint-specific method to assess the potential impact of new agricultural technology: the case of frost resistant potato for the Altiplano (Peru and Bolivia). Agricultural Systems 76(3): 895-911. doi: 10.1016/ S0308-521X(02)00081-1.

Holzkämper A., Calanca P., Fuhrer J., 2011. Analyzing climate effects on agriculture in time and space. 1st Conference on Spatial Statistics 2011 - Mapping Global Change 3: 58-62. doi: 10.1016/j.proenv.2011.02.011.

Holzkämper A., Fossati D., Hiltbrunner J., Fuhrer J., 2015. Spatial and temporal trends in agro-climatic limitations to production potentials for grain maize and winter wheat in Switzerland. Regional Environmental Change 15(1): 109-122. doi: 10.1007/s10113-014-0627-7.

Islam A., Ahuja L.R., Garcia L.A., Ma L., Saseendran A.S., Trout T.J., 2012. Modeling the impacts of climate change on irrigated corn production in the Central Great Plains. 
Agricultural Water Management 110: 94-108. doi: 10.1016/j. agwat.2012.04.004.

Jayathilaka P.M.S., Soni P., Perret S.R., Jayasuriya H.P.W., Salokhe V.M., 2012. Spatial assessment of climate change effects on crop suitability for major plantation crops in Sri Lanka. Regional Environmental Change 12(1): 55-68. doi: 10.1007/s10113-011-0235-8.

Jose A.M., Francisco R.V., Cruz N.A., 1996. A study on impact of climate variability/change on water resources in the Philippines. Global Change: Anthropogenic Processes and Indicators for Sustainable Development 33(9): 16871704. doi: 10.1016/0045-6535(96)00185-3.

Joss B.N., Hall R.J., Sidders D.M., Keddy T.J., 2008. Fuzzy-logic modeling of land suitability for hybrid poplar across the Prairie Provinces of Canada. Environmental Monitoring and Assessment 141(1-3): 79-96. doi: 10.1007/s10661007-9880-2.

Kampichler C., Barthel J., Wieland R., 2000. Species density of foliage-dwelling spiders in field margins: a simple, fuzzy rule-based model. Ecological Modelling 129(1): 87-99.

Kim K.S., Beresford R.M., 2011. Use of a Climatic Rule and Fuzzy Sets to Model Geographic Distribution of Climatic Risk for European Canker (Neonectria galligena) of Apple. Phytopathology 102(2): 147-157. doi: 10.1094/PHYTO-01-11-0018.

Kim J., Sang W., Shin P., Cho H., Seo M., Yoo B., Kim K.S., 2016. Evaluation of regional climate scenario data for impact assessment of climate change on rice productivity in Korea. Journal of Crop Science and Biotechnology 18(4): 257-264. doi: 10.1007/s12892-015-0103-z.

Ko J., Ahuja L.R., 2014. Global warming likely reduces crop yield and water availability of the dryland cropping systems in the U.S. Central Great Plains. Journal of Crop Science and Biotechnology 16(4): 233-242. doi: 10.1007/ s12892-013-0106-6.

Ko J., Kim H.-Y., Jeong S., An J.-B., Choi G., Kang S., Tenhunen J., 2014. Potential impacts on climate change on paddy rice yield in mountainous highland terrains. Journal of Crop Science and Biotechnology 17(3): 117-126. doi: 10.1007/s12892-013-0110-x

Kroschel J., Sporleder M., Tonnang H.E.Z., Juarez H., Carhuapoma P., Gonzales J.C., Simon R., 2013. Predicting climate-change-caused changes in global temperature on potato tuber moth Phthorimaea operculella (Zeller) distribution and abundance using phenology modeling and GIS mapping. Agricultural and Forest Meteorology 170: 228-241. doi: 10.1016/j.agrformet.2012.06.017.

Kuang W., Xianjiang Y., Xiuqing C., Yafeng X., 2012. Experimental Study on Water Production Function for Waterlogging Stress on Corn. 2012 International Conference on Modern Hydraulic Engineering 28: 598-603. doi: 10.1016/j. proeng.2012.01.775.

Kurtener D., Torbert H.A., Krueger E., 2008. Evaluation of Agricultural Land Suitability: Application of Fuzzy Indicators, in: Gervasi, Murgante, Laganà, Taniar, Mun, Gavrilova (Eds.): Computational Science and Its Applications - ICCSA 2008, Lecture Notes in Computer Science. Springer Berlin Heidelberg, pp. 475-490.

Lane A., Jarvis A., 2007. Changes in Climate will modify the Geography of Crop Suitability: Agricultural Biodiversity can help with Adaptation. Journal of Semi-arid Tropical Agricultural Research 4(1): 1-12.

Lansigan F.P., de los Santos W.L., Hansen J., 2007. Delivering Climate Forecast Products to Farmers: Ex Post Assessment of Impacts of Climate Information on Corn Pro- duction Systems in Isabela, Philippines, in: Sivakumar, Hansen (Eds.), Climate Prediction and Agriculture. Springer Berlin Heidelberg, pp. 41-48.

Lansigan F.P., Salvacion A.R., 2007. Assessing the effect of climate change on rice and corn yields in selected provinces in the Philippines, in: 10th National Convention on Statistics (NCS). Presented at the 10th National Convention on Statistics (NCS), Mandaluyong City.

Lewis S.M., Fitts G., Kelly M., Dale L., 2014. A fuzzy logic-based spatial suitability model for drought-tolerant switchgrass in the United States. Computers and Electronics in Agriculture 103: 39-47. doi: 10.1016/j.compag.2014.02.006.

Meza F.J., Silva D., Vigil H., 2008. Climate change impacts on irrigated maize in Mediterranean climates: Evaluation of double cropping as an emerging adaptation alternative. Agricultural Systems 98(1): 21-30. doi: 10.1016/j. agsy.2008.03.005.

Mighty M.A., 2015. Site suitability and the analytic hierarchy process: How GIS analysis can improve the competitive advantage of the Jamaican coffee industry. Applied Geography 58: 84-93. doi: 10.1016/j.apgeog.2015.01.010.

Naughton C.C., Lovett P.N., Mihelcic J.R., 2015. Land suitability modeling of shea (Vitellaria paradoxa) distribution across sub-Saharan Africa. Applied Geography 58: 217-227. doi: 10.1016/j.apgeog.2015.02.007.

Orlandini S., Marta A.D., D’ Angelo I., Genesio R., 2003. Application of fuzzy logic for the simulation of Plasmopara viticola using agrometeorological variables*. EPPO Bulletin 33(3): 415-420. doi: 10.1111/j.1365-2338.2003.00666.x.

Ovalle-Rivera O., Läderach P., Bunn C., Obersteiner M., Schroth G., 2015. Projected Shifts in Coffea arabica Suitability among Major Global Producing Regions Due to Climate Change. PLoS ONE 10(4): e0124155. doi: 10.1371/ journal.pone.0124155.

PAGASA [Philippine Atmospheric Geophysical and Astronomical Services Administration], 2017. Online: pagasa. dost.gov.ph/index.php/climate-of-the-philippines (accessed 8 February 2017).

Papageorgiou E.I., Markinos A., Gemptos T., 2009. Application of fuzzy cognitive maps for cotton yield management in precision farming. Expert Systems with Applications 36(10): 12399-12413. doi: 10.1016/j.eswa.2009.04.046.

Parthasarathy U., Jayarajan K., Johny A.L., Parthasarathy V.A., 2008. Identification of suitable areas and effect of climate change on ginger - a GIS study. Journal of Spices and Aromatic Crops 17(2): 61-68.

PSA-BAS [Philippine Statistics Authority-Bureau of Agricultural Statistics], 2015. CountrySTAT Philippines. Online: countrystat.bas.gov.ph (accessed 9 December 2015).

Ramirez-Cabral N.Y.Z., Kumar L., Taylor S., 2016. Crop niche modeling projects major shifts in common bean growing areas. Agricultural and Forest Meteorology 218219: 102-113. doi: 10.1016/j.agrformet.2015.12.002.

Ramirez-Villegas J., Jarvis A., Läderach P., 2013. Empirical approaches for assessing impacts of climate change on agriculture: The EcoCrop model and a case study with grain sorghum. Agricultural and Forest Meteorology 170: 67-78. doi: 10.1016/j.agrformet.2011.09.005.

Ray D.K., Gerber J.S., MacDonald G.K., West P.C., 2015. Climate variation explains a third of global crop yield variability. Nat Commun 6.

Reshmidevi T.V., Eldho T.I., Jana R., 2009. A GIS-integrated fuzzy rule-based inference system for land suitability 
evaluation in agricultural watersheds. Agricultural Systems 101(1-2): 101-109. doi: 10.1016/j.agsy.2009.04.001.

Riahi K., Rao S., Krey V., Cho C., Chirkov V., Fischer G., Kindermann G., Nakicenovic N., Rafaj P., 2011. RCP 8.5-A scenario of comparatively high greenhouse gas emissions. Climatic Change 109(1-2): 33-57. doi: 10.1007/ s10584-011-0149-y.

Rübbelke D., Vögele S., 2011. Impacts of climate change on European critical infrastructures: The case of the power sector. Environmental Science \& Policy 14(1): 53-63. doi: 10.1016/j.envsci.2010.10.007.

Salvacion A.R., 2009. Assessing Potential Impact of Changing Climate on Agricultural Crop Production in the Philippines (MSc Thesis). University of the Philippines Los Baños, College, Laguna.

Salvacion A.R., 2015. Climatic Change Impact on Corn Productivity in the Philippines. International Journal of Sciences: Basic and Applied Research (IJSBAR) 23(1): 54-68.

Salvacion A.R., Martin A.A., 2016. Climate change impact on corn suitability in Isabela province, Philippines. Journal of Crop Science and Biotechnology 19(3): 223-229. doi: 10.1007/s12892-016-0019-2.

Salvacion A.R., Pangga I.B., Cumagun C.J.R., 2015. Assessment of mycotoxin risk on corn in the Philippines under current and future climate change conditions. Reviews on Environmental Health 30(3): 135-142. doi: 10.1515/ reveh-2015-0019.

Scherm H., 2000. Simulating uncertainty in climate-pest models with fuzzy numbers. Environmental Pollution 108(3): 373-379. doi: 10.1016/S0269-7491(99)00216-X.

Sicat R.S., Carranza E.J.M., Nidumolu U.B., 2005. Fuzzy modeling of farmers' knowledge for land suitability classification. Agricultural Systems 83(1): 49-75. doi: 10.1016/j. agsy.2004.03.002.

Sivakumar M.V.K., Hansen J., 2007. Climate Prediction and Agriculture: Summary and the Way Forward, in: Sivakumar, Hansen (Eds.), Climate Prediction and Agriculture. Springer Berlin Heidelberg, pp. 1-13.
Sys C., Van Ranst E., Debaveye J., Beernaert F., 1993. Land Evaluation: Part III - Crop Requirments. Agricultural Publications, Brussels, Belgium.

Triantafilis J., Ward W.T., McBratney A.B., 2001. Land suitability assessment in the Namoi Valley of Australia, using a continuous model. Soil Research 39(2): 273-289.

Van Ranst E., Tang H., Groenemam R., Sinthurahat S., 1996. Application of fuzzy logic to land suitability for rubber production in peninsular Thailand. Geoderma 70(1): 1-19. doi: 10.1016/0016-7061(95)00061-5.

Wang Y., Tan Z., Sun G., 2015. The Impact of Climate Change on the Potential Suitable Distribution of Major Crops in Zambia and the Countermeasures, in: Li, Chen (Eds.), Computer and Computing Technologies in Agriculture VIII: 8th IFIP WG 5.14 International Conference, CCTA 2014, Beijing, China, September 16-19, 2014, Revised Selected Papers. Springer International Publishing, Cham, pp. 460-472.

Yan-Ling S., De-Liang C., Yan-Ju L., Ying X., 2012. The Influence of Climate Change on Winter Wheat during 20122100 under A2 and A1B Scenarios in China. Advances in Climate Change Research 3(3): 138-146. doi: 10.3724/ SP.J.1248.2012.00138.

Zabel F., Putzenlechner B., Mauser W., 2014. Global Agricultural Land Resources - A High Resolution Suitability Evaluation and Its Perspectives until 2100 under Climate Change Conditions. PLoS ONE 9(9): e107522. doi: 10.1371/journal.pone.0107522.

Zaidi P.H., Rafique S., Rai P.K., Singh N.N., Srinivasan G., 2004. Tolerance to excess moisture in maize (Zea mays L.): susceptible crop stages and identification of tolerant genotypes. Field Crops Research 90(2-3): 189-202. doi: 10.1016/j.fcr.2004.03.002.

Zhang X., Cai X., 2011. Climate change impacts on global agricultural land availability. Environmental Research Letters 6(1): 14014

Zhao J., Guo J., Xu Y., Mu J., 2015. Effects of climate change on cultivation patterns of spring maize and its climatic suitability in Northeast China. Agriculture, Ecosystems \& Environment 202: 178-187. doi: 10.1016/j.agee.2015.01.013. 